\title{
Optimisme Mahasiswa Universitas Bhayangkara Jakarta Raya Yang Menjalani Perkuliahan Daring Di Tengah Pandemi Covid-19
}

\author{
Timorora Sandha Perdhana ${ }^{1, *}$ \\ ${ }^{1}$ Fakultas Psikologi; Universitas Bahyangkara Jakarta Raya; Jl. Perjuangan No.81, \\ Rt.003/Rw.002, Marga Mulya, Kec. Bekasi Utara; Telp. (021) 88955882: email: \\ timorora.sandha@dsn.ubharajaya.ac.id \\ * Korespondensi: e-mail: timorora.sandha@dsn.ubharajaya.ac.id \\ Submitted: 12/01/2022; Revised: 15/01/2022; Accepted: 22/01/2022; Published: $31 / 01 / 2022$
}

\begin{abstract}
The covid-19 crisis has forced education sisytems to find alternative face-to-face instrunction. As a result online lectures have been used by teachers and students. There are many problems faced by students when taking online lectures that can have negative impact on the continuity of lectures. Students must be optimistic in dealing with problems that occur during lectures in the midst of Covid-19 pandemic. This study aims to determine the level of students optimism during online lectures. This study involved 100 Bhayangkara Jakarta Raya college students. The result of this study indicate that the highest score of students optimism is at a high level with a value of $76 \%$, and $24 \%$ of students are in the moderate category of optimism. The average level of students optimism is in the high category, meaning that students have confidence in facing all obstacle while undergoing online lectures.
\end{abstract}

Keywords: Covid-19, Online Lectures, Optimist

\begin{abstract}
Abstrak
Pandemi Covid-19 mengharuskan sistem pendidikan berubah dari tatap muka menjadi pembelajaran daring. Banyaknya permasalahan yang dihadapi mahasiswa saat menjalani perkuliahan daring dapat berdampak buruk bagi keberlangsungan perkuliahan. Pentingnya sikap optimis agar mahasiswa memiliki keyakinan untuk tetap mengatasi segala hambatan dalam menjalani perkuliahan di tengah pandemi Covid-19. Penelitian ini bertujuan mengetahui tingkat optimisme mahasiswa Universitas Bhayangkara Jakarta Raya dalam menjalani perkuliahan daring. Jumlah subjek yang digunakan dalam penelitian ini sebanyak 100 mahasiswa Universitas Bhayangakra Jakarta Raya. Hasil penelitian menunjukan bahwa skort tertinggi mahasiswa berada pada kriteria tinggi dengan nilai $76 \%$, dilanjutkan dengan kriteria sedang $24 \%$. Rata-rata gambaran optimisme mahasiswa di Universitas Bhayangkara Jakarta Raya berada pada kategori tinggi artinya mahasiswa bersikap positif dan memiliki keyakinan dalam menghadapi hambatan selama melakukan proses pembelajaran secara daring.
\end{abstract}

Kata kunci: Covid-19, Kuliah Daring, Optimis

\section{Pendahuluan}

Covid-19 adalah virus dari Sars-Cov-2 dengan gejala umum demam tinggi, batuk, gangguan pernapasan yang dapat menyebabkan penderitanya mengalami pneumonia, gagal ginjal hingga kematian (Kemenkes, 2020). Pandemi covid-19 merupakan fenomena luar biasa karena virus yang sangat berbahaya ini dapat menular dengan mudah. Awal tahun 2020 
sampai dengan bulan mei 2020 saja jumlah kasus pasien positif covid 19 di dunia adalah sebanyak 3.396.168 kasus. Dari jumlah tersebut diketahui 239.376 orang meninggal dunia. Sementara 1.079.572 pasien telah dinyatakan sembuh (Mukaromah, 2020).

Dalam mengurangi penyebaran virus Covid-19 pemerintah mengeluarkan kebijakan berupa bekerja dari rumah, beribadah dari rumah, belajar dari rumah, melakukan social distancing dan menggunakan masker. Berdasarkan surat edaran Kementrian Pendidikan dan Kebudayaan No. 1 tahun 2020 tentang pencegahan covid-19 diperguruan tinggi dengan cara melaksanakan pembelajaran jarak jauh dan mahasiswa belajar dari rumah melalui pembelajaran berbagai platform daring (Kemendikbud, 2020). Kebijakan tersebut sangat berpengaruh besar pada dunia pendidikan, proses pembelajaran tatap muka diindikasi dapat mempercepat penyebaran coivd-19. Sehingga pada awal maret 2020 semua institusi pendidikan berpindah menggunakan sistem pembelajaran jarak jauh atau pembelajaran daring (Sari, 2020).

Terdapat sejumlah tantangan dalam mengimplementasikan pembelajaran daring di negara berkembang diantaranya dalam hal keterbatasan fasilitas, faktor kesipan sumber daya manusia, baik pengajar maupun peserta didik (Issa \& Jaaron, 2017). Tidak semua pelajar, siswa dan mahasiswa terbiasa dengan pembelajaran melalui daring. Apalagi guru dan dosen yang masih banyak belum mahir mengajar dengan menggunakan teknologi internet atau media sosial, sehingga pada prosesnya pembelajaran tidak berjalan lancar seperti proses pembelajaran tatap muka (Purwanto, 2020).

Kesulitan-kesulitan yang tidak dapat diatasi akan berdampak buruk bagi keberlangsungan pendidikan maasiswa (Hart, 2012). Untuk dapat mengatasi kesulitan yang dihadapi tersebut mahasiswa harus tetap bersikap positif dalam menghadapi segala kesulitan yang mereka hadapi selama pembelajaran daring. Sikap positif sangatlah diperlukan dalam menghadapi kesulitan yang sedang dialami.

Optimisme menjadi salah satu konstruk psikologi yang dapat mempengaruhi kehidupan individu, dengan bersikap optimis individu akan memiliki keyakinan tentang masa depan mereka yang membuat mereka melanjurkan upaya menuju suatu tujuan meski mengalami kesulitan (Hanssen et al., 2015). optimisme adalah sikap positif terhadap dunia yang mengarahkan individu kepada kesuksesan di sekolah, hubungan, karier dan banyak bagian lainnya dalam kehidupan. Individu dengan optimisme yang tinggi akan menganggap hambatan dan kesulitan sebagai langkah positif dalam mencapai keberhasilan (Oktaviani \& Dwatra, 2021).

Mahasiswa harus memiliki optimisme dalam dirinya karena berpengaruh terhadap proses keberhasilan studi yang ditempuh. Berdasarkan penelitian Hasnayati (2020) yang bertujuan untuk mengetahui perbedaan tingkat optimisme mahasiswa di Universitas Negeri Malang menunjukan jika optimisme mahasiswa Universitas Negeri Malang berada di tingkat tinggi artinya mahasiswa memiliki sikap positif dan mampu memandang suatu peristiwa yang buruk hanyalah sementara. Hasil penelitian tersebut menunjukan bahwa dengan bersikap optimis mahasiswa akan memiliki keyakinan serta memandang suatu hambatan-hambatan 
perkuliahan secara daring serta peristiwa buruk seperti pandemi covid-19 hanyalah bersifat sementara. Sebaliknya Kurangnya optimisme membuat mahasiswa merasa ragu akan akan kemampuan yang dimiliki (Masithoh \& Hidayat, 2018). Dengan menjadi optimistik dapat memiliki pengaruh dan dampak positif pada kemampuan individu untuk beradaptasi dengan stresor (Sabouripour dan Roslan, 2015).

Dengan bersikap optimis mahasiswa dapat menumbuhkan kepercayaan dan kekuatan sehingga kesulitan dan hambatan yang dihadapi khusunya bagi mahasiswa Universita Bhayangkara Jakarta Raya yang sedang menjalani kuliah daring akan menjadi dorongan positif untuk mencapai keberhasilan dalam perkuliahaan. Oleh karena itu tujuan penelitian ini untuk melihat gambaran tingkat optimisme mahasiswa yang sedang melakukan pembelajaran secara daring.

\section{Metode Penelitian}

Penelitian ini menggunakan metode kuantitatif. Metode kuantitatif adalah tipe penelitian yang memiliki ara pandang deduktif, yaitu menjelasan sesuatu dari yang bersifat umum ke khusus dari jumlah subjek minimal 30.

Subjek dalam penelitian ini adalah mahasiswa aktif Universitas Bhayangkara Jakarta Raya yang mengikuti perkuliahan daring. Penelitian ini melibatkan 100 orang mahasiswa aktif Universitas Bhayangakara Jakarta Raya sebagai sampel penelitian. Metode yang digunakan dalam pengambilan sampel adalah teknik snowball, yaitu saat bertemu satu sujek tertentu kita bisa menemukan subjek lain pula dengan karakteristik yang sama (Periantolo, 2016).

Pengumpulan data dalam penelitian ini menggunakan kuesioner yaitu teknik yang terdiri dari aitem atau pernyataan tertulis yang akan dijawab oleh subjek mengenai suatu variabel yang diteliti. Skala yang digunakan dalam penelitian ini adalah skala likert dengan lima pilihan jawaban 5 (Sangat Sesuai), 4 (Sesuai), 3 (Netral), 2 (Tidak Sesuai) dan 1 (Sangat Tidak Sesuai).

Tabel 1. Skala Likert

\begin{tabular}{cc}
\hline Pilihan jawaban & Skor \\
\hline Sangat sesuai & 5 \\
Sesuai & 4 \\
Netral & 3 \\
Tidak sesuai & 2 \\
Sangat tidak sesuai & 1 \\
\hline
\end{tabular}

Sumber: Hasil Penelitian (2021)

Instrumen pengumpulan data dalam penelitian ini menggunakan skala optimisme, grand teori Seligman (2008) yang terdiri dari 3 aspek optimisme yaitu permanence, pervasivness, personalization teknik analisis data menggunakan distribusi frekuensi dan presentase. 


\section{Hasil dan Pembahasan}

\subsection{Uji Asumsi}

Uji normalitas dilakukan untuk mengetahui bagaiamana sebaran data penelitian yang diperoleh dengan menggunakan uji normalitas liliefors, apakah sebaran datanya normal atau tidak normal hasil pengujian dijabarkan pada tabel berikut

Tabel 2. Uji Normalitas

\begin{tabular}{crc}
\hline Variabel & Sig & Keterangan \\
\hline Optimisme & 0.2 & Sebaran data terdistribusi normal
\end{tabular}

Sumber: Hasil Pengolahan Data (2021)

Distribusi data dikatakan normal apabila nilai $\mathrm{p}$ (signifikansi) $>0.05$. berdasarkan tabel diatas dapat dilihat bahwa pada optimisme, nilai signifikansi adalah 0,200 hal ini menunjukan bahwa data penelitian terdistribusi secara normal.

\subsection{Kategorisasi Optimisme Mahasiswa}

Uji kategorisasi menggunakan teknik analisis presentase SPSS ditemuka dari 100 sampel hasil kategorisasi menunjukan 76 mahasiswa dengan presentase $76 \%$ memiliki optimisme yang tinggi, dan 24 mahasiswa dengan presentase $24 \%$ memiliki optimisme sedang.

Tabel 3. Kategorisasi Optimisme

\begin{tabular}{cccc}
\hline Kategori & Skor & Jumlah & Persen \\
\hline Rendah & $\mathrm{X}<53$ & 0 & $0 \%$ \\
Sedang & $53<\mathrm{X}<84$ & 24 & $24 \%$ \\
Tinggi & $84>$ & 76 & $76 \%$ \\
\hline Sumber: Hasil Pengolahan Data (2021) & & &
\end{tabular}

\subsection{Kategorisasi Optimisme Mahasiswa Berdasarkan Jenis Kelamin}

Tabel 4 memperlihatkan kategorisasi optimisme berdasarkan jenis kelamin. Pada jenis kelamin laki-laki dengan kategorisasi optimisme tinggi sebanyak 39 orang dan perempuan dengan kategorisasi tinggi sebanyak 37 orang, kemudian laki-laki dengan kategorisasi sedang sebanyak 7 orang dan perempuan dengan kategorisasi sedang sebanyak 17 orang.

Tabel 4. Kategorisasi Berdasarkan Jenis Kelamin

\begin{tabular}{ccc}
\hline Kategori & Laki-Laki & Perempuan \\
\hline Rendah & 0 & 0 \\
Sedang & 7 & 17 \\
Tinggi & 39 & 37 \\
\hline Sumber: Hasil Pengolahan Data (2021) & &
\end{tabular}

\subsection{Presentase Subvariabel Optimisme}

Pada tabel 5 dapat dilihat mayoritas mahasiswa Universitas Bhayangkara Jakarta Raya pada suvariabel permanence sebesar $72 \%$ artinya mahasiswa mempercayai penyebab baik bersifat menetap, pada subvariabel pervasivness sebesar $75 \%$ artinya mahasiswa mampu memberikan penjelasan secara spesifik ketika menghadapi peristiwa buruk, kemudian pada subvariabel personalization sebesar $80 \%$ artinya mahasiswa meyakini suatu peristiwa disebabkan oleh faktor dalam diri. 
Tabel 5. Presetase Subvariabel

\begin{tabular}{cc}
\hline Aspek & Presentase \\
\hline Permanence & $72 \%$ \\
Pervasivness & $75 \%$ \\
Personalization & $80 \%$ \\
\hline
\end{tabular}

Sumber: Hasil Pengolahan Data (2021)

\subsection{Pembahasan}

Setelah dilakukan analisis kuantitatif dengan menggunakan SPSS versi 23 ditemukan bahwa tingkat optimisme mahasiswa Universitas Bhayangkara Jakarta Raya yang menjalani perkuliahan daring berada pada kategori tinggi dengan presentase $76 \%$. Artinya sebagian besar mahasiswa memiliki optimisme yang tinggi dalam proses pendidikan sehingga mahasiswa yakin dapat mengatasi hambatan dan tantangan yang terjadi selama mengikuti perkuliahan daring.

Pada mahasiswa yang memiliki optmisme tinggi mampu menunjukan sikap-sikap optimis seperti menilai suatu peristiwa baik bersifat menetap permanence, mampu menjelaskan secara spesifik ketika menghadapi prestiwa buruk pervasivness, dan meyakini suatu peristiwa disebabkan oleh faktor dalam diri personalization (Seligman, 2008). Berdasarkan subvariabel diketahui pada aspek permanence sebesar $72 \%$, aspek pervasivness sebesar $75 \%$, dan pada aspek personalization sebesar $80 \%$, hal ini menunjukan bahwa pada aspek personalization mendominasi optimisme mahasiswa Universitas Bhayangkara Jakarta Raya yang artinya individu meyakini suatu permasalahan yang terjadi baik secara internal ataupun eksternal. Individu yang optimis adalah mereka yang meyakini suatu permasalahan secara eksternal dan percaya bahwa kejadian-kejadian baik yang terjadi dalam hidupnya berasal dari internal (Seligman, 2008).

\section{Kesimpulan}

Kesimpulan pada penelitian ini adalah berdasarkan temuan penelitian bahwa tingkat optimisme mahasiswa universitas bhayangkara jakarta raya berada pada kategori tinggi dengan presentase sebesar $76 \%$. Tidak ada perbedaan yang signifikan pada tingkat optimisme mahasiswa berdasarkan jenis kelamin. Aspek personalization merupakan aspek yang paling mendominasi dalam optimisme mahasiswa dengan presentase sebesar $80 \%$.

\section{Daftar Pustaka}

Bakia, M., Shear, L., Toyama, Y., \& Lasseter, A. (2012). Understanding the implication of Online Learning for Educational Productivity. Educational Technology. 1-75.

Hanssen, M. M. Et al. (2015). Optimism, Motivational Coping and Well-Being: Evidence Supporting the Importance of Flexible Goal Adjusment. Journal of Happines Studies. Springer Netherlands, 16(6). 1525-1537.

Hart, C (2020). Factors Associated With Students Presistence in an Online Program of Study: A Review of the Literature. Journal of Interactive Online Learning. 11(1). 19-42.

Hasnayati, A., Pramesti, C., A., Adam, F. T., \& Noorizki, R. D. (2020). Tingkat Optimisme pada mahasiswa universitas negeri malang. In Seminar Nasional Psikologi UM. 1(1). 
Isaa, R., \& Jaaron, A. A. M. (2017). Measuring e-learning readlines: The case of Palestinian public secondary schools. International journal of technology enchanced learning, 9(4), 319-338.

Kementrian kesehatan republik indonesia. (2020). Hindari lansia dari covid-19. Diakses dari htttp://www.padk.kemkes.go.id/article/read/2020/04/23/21/hindari-lansia-dari-covid19.html

Kementrian Pendidikan dan Kebudayaan (2020). Surat edaran jenderal pendidikan tinggi kemendikbud nomor 1 tahun 2020. Diakses dari http://ldikti3.kemendikbud.go.id/v6/wpcontent/upload/2020/04/Surat-Edaran-Direktorat-Jenderal-Pendidikan-TinggiKemdikbud-Nomor-1-Tahun-2020-3.pdf

Macdonald, L. (2018). You Can Be an Optimist. New York: The Rosen Publishing Group, Inc.

Mukaromah, V. F. (2020). Update virus corona dunia 2 mei: 3,4 juta orang terinfeksi, 1,08 juta orang sembuh diakses dari http://www.kompas.com/tren/read/2020/05/02/071440965/update-virus-corona-dunia-2mei-34-juta-orang-terinfeksi-108-juta-orang.html

Munawaroh, E. B. I., Nugraheni, E. P., Sofyan, A., Utomo, D. P., \& Arinata, F. S. (2020). College Students Academic Resilience Profile. International journal of scientific \& technology research. (9), ISSN 2277-8616.

Periantolo, J.(2016). Penelitian Kuantitatif Untuk Psikologi. Januari: Pustaka Pelajar.

Purwanto, A. et al. (2020). Studi Eksploratif Dampak Pandemi Covid 19 terhadap Pembelajaran Online di Sekolah Dasar. Journal of Education, Psychology and Counseling. 2(1), 1-12.

Sabouripierpour, F. \& Roslan, S. B. (2015). Resilience, Optimism, and Social Support among International Students. Canadian Cender of Science and Education. 11, (15) ISSN 1911-2017.

Sari, D. (2020). Peran Adaptif Tiga Universitas di Jabodetabek dalam menghadapi Sistem Belajar Online selama pandemi COVID 19. 25-32.

Seligman, M. E. P. (2008). Menginstal Optimisme. Bandung: Salamadani 